\title{
The Adoption of IFRS 3: The Effects of Managerial Discretion and Stock Market Reactions
}

\author{
Mattias Hamberg \\ School of Business, Economics, and Law, \\ Göteborg University, Box 610, 40530 Göteborg, \\ Sweden \\ mattias.hamberg@handels.gu.se \\ Mari Paananen* \\ Business School \\ University of Hertfordshire, \\ College Lane, Hatfield, AL10 9AB \\ United Kingdom \\ m.paananen@herts.ac.uk \\ Jiri Novak \\ Institute of Economic Studies \\ Charles University in Prague \\ novakji@fsv.cuni.cz
}




\title{
The Adoption of IFRS 3: The Effects of Managerial Discretion and Stock Market Reactions
}

\begin{abstract}
:
In recent years several accounting standards issued by the IASB substitute measures of fair value for historical cost, and give managers the discretion to determine the fair value without an actual market for the asset. We document the accounting consequences of the adoption of IFRS 3 and the stock market's reaction using data from Sweden. After the adoption of IFRS 3 in January 2005 the amount of capitalized goodwill has increased substantially. Goodwill impairments under IFRS are considerably lower than goodwill amortizations and impairments made under Swedish GAAP. An analysis of economic incentives influencing the impairment decision at the initial adoption of IFRS 3 show some evidence that tenured management is negatively associated with the impairment decision. However, most firms did not reclassify goodwill or make additional impairments. Firms with substantial amounts of goodwill yielded abnormally high returns despite that they earned abnormally low earnings. Investors seem to, correctly or incorrectly, have viewed the IFRS 3 related boost in earnings as an indication of higher future cash flows.
\end{abstract}

Keyword: goodwill, IFRS 3, impairments, managerial discretion, Sweden 


\section{Introduction}

In recent years standard-setters like the International Accounting Standards Board (IASB) have substituted historical cost-based measures with fair value-based measures (illustrated by the upcoming new standard on fair value measurement; ED/2009/5), with intentions to increase the decision usefulness of accounting information (Hitz, 2007). The IASB has pushed the use of fair value measures to non-financial assets where market-based measures are derived from managements' own expectations of future cash flows. As pointed out by Landsman (2007) and others, mixing fair values and managerial discretion is cumbersome and the pros and cons of conservatism are now frequently discussed from both conceptual (Hitz, 2007; Chen et al., 2007) and empirical standpoints (e.g. LaFond and Watts, 2008). While empirical accounting research might be unable to directly answer standard-setting questions (Beaver, 1998) it can enlighten decision makers by providing ex post empirical evidence (Barth, 2006). Our study provides evidence of how the new standard for business combinations (IFRS 3) affects financial reporting and the stock market's reactions to the new information.

The Financial Accounting Standards Board's (FASB) adoption of SFAS 142 in 2001, changed goodwill accounting from amortization of historical cost to an impairment-only approach.

Empirical evidence from the U.S. indicates that this new approach provides a marginal increase in decision usefulness (e.g. Chen et al., 2004; Ahmed and Guler, 2007), but also that accounting choices associated with the mandatory first-time adoption were driven by economic incentives (Beatty and Weber, 2006). There are important differences between the U.S and the European setting. As U.S. firms often amortized goodwill over extensive periods of time the abolishment of amortizations had a limited effect on their reported earnings. When goodwill is amortized over shorter periods of time, as in most European countries, the effect on reported earnings is much greater, which strengthens the incentive to act opportunistically. In addition, a number of studies have claimed that earnings management is more common in Europe than in the U.S. (Leuz et al., 2003; Lang et al., 2006). The combination of greater economic incentives and more prevailing earnings management makes the European adoption of IFRS 3 an interesting study object. However, as the standard was introduced at the same time as the general European adoption of 
IFRS, it is difficult to disentangle the IFRS 3 effects from the effects of all other standards. To address this, we use Swedish data where standard-setters have translated and implemented IFRS for more than 15 years and where the mandatory IFRS adoption in reality only introduced a few new standards. Studying accounting choices in a Swedish setting is also interesting as Swedish accounting is deemed to be of high quality (La Porta et al., 1998).

Our study contributes to the accounting literature in three ways. First, we document the accounting consequences of the switch to an impairment-only approach. According to the IFRS restatements firms (with goodwill) deemed IFRS 3 as the by far most important change (93.3\%). The mandatory IFRS adoption increased earnings, mainly because of the abolished goodwill amortizations. On average, goodwill impairments under IFRS 3 are considerably smaller than the amortizations and impairments reported under Swedish GAAP. Combined with a high acquisition frequency, the level of goodwill soared in the years 2005 to 2007. Only a smaller part of new acquired goodwill has been identified as specific acquired intangible assets. And, impairments do not increase in the years following the IFRS 3 adoption. The effect of the IFRS 3 adoption is that firms have more unspecific intangible assets than ever before making future earnings more dependent on managers' discretionary decisions.

Second, we examine how managers made use of the discretion given to them in association with the first time adoption of IFRS 3. We find that few firms reclassified material amounts of goodwill to other specific intangible assets. There is some evidence that tenured management is more reluctant to impair goodwill at the time of the IFRS 3 adoption. We also find weak indications that firms with considerable proportions of goodwill are reluctant to initiate any impairment. In our sample most firms merely reversed the goodwill amortizations from the transition year.

Third, we examine investors' reactions to increased earnings following the abolishment of amortizations. Changes in the accounting for goodwill affect share prices, if either (1) investors perceive the impairment-only approach to provide new value relevant information, or (2) investors incorrectly interpret an increase in earnings (caused by the abolishment of goodwill amortizations) as an indication of higher future cash flows. Firms with large amounts of goodwill 
have lower abnormal earnings in a seven month IFRS transition window but they yield considerably higher abnormal returns than firms without proportionally large goodwill balances. Interestingly, firms with substantial amounts of goodwill are larger; however, there is no difference in abnormal returns among larger firms. The reason for this appears to be that the positive effect on earnings caused by abolished amortizations is comparatively smaller for large firms and not enough to counter the difference in abnormal earnings.

The remainder of the paper is organized as follows. Section two outlines the regulatory framework. Section three discusses research on managerial discretion and formulates our hypotheses. The fourth section describes the data and research methodology. Section five provides the empirical analysis and finally, the sixth section concludes the paper.

\section{The regulatory framework}

Goodwill is largely the difference between the purchase price and the value of an acquired firm's equity. Capitalized goodwill is an intangible asset that is an indicator of excess future cash flows either from the acquired entity itself or from the combination of the acquired and acquiring entities (Johnson and Petrone, 1998). Most accounting regulators recognize acquired goodwill although internally generated goodwill is generally not recognized. The somewhat inconsistent treatment of goodwill is explained by the verifiability of acquired goodwill arising from an open market transaction (as noted in both IFRS 22 and APB 17). Once goodwill is capitalized, the question is how to subsequently account for it. Prior to the U.S. adoption of SFAS 142, most accounting regulators required that goodwill must be amortized over a certain period of time. The length of this period varied substantially between local GAAPs (APB 17 allowed U.S. firms a maximum of 40 years and IAS 22 allowed 10 years). Many Swedish firms applied a conservative view of goodwill. Until 2002, the accounting standard RR 1:96 required goodwill to be amortized over five years unless a longer economic life can be estimated with reasonable certainty (as required by Swedish law: ÅRL 4:2-4). RR 1:00 issued by Redovisningsrådet in 2002, allowed an economic life of maximum 20 years, but many firms continued to use a shorter economic life. ${ }^{1}$ 
The issue of SFAS 142 was a major change in how to account for goodwill. Under SFAS 142 goodwill is measured at the smallest cash generating unit using discounted cash flow techniques to reflect the estimates and expectations of market participants. That is, SFAS 142 calls for fair value estimates of goodwill that relies on a managerial discretion, which paved the way for IASB's work on IFRS 3.

Under IAS 22 the difference between the purchase price and the value of the acquired firm's book value of equity was capitalized as goodwill. IFRS 3, on the other hand, requires an identification of specific intangible assets in the acquired entity (such as patents, licenses and trademarks) that are to be capitalized separately. Depending on the nature of these intangibles they can be kept indefinitely or amortized over a maximum economic life of 20 years. At the time of the acquisition, two questions arise: (1) what is the value of identifiable intangible assets, and (2) how long is the economic life of these assets?

IFRS 3 abandons the amortization of capitalized goodwill and instead the book value of goodwill is tested for impairment on a regular basis (IAS 36-Impairment of Assets). Goodwill is allocated to the lowest level of cash-generating units (CGU). The carrying amount of the CGU's goodwill is compared with its recoverable amount. If the recoverable amount is the higher of (1) the fair value, less costs to sell, and (2) its value in use, then there is no goodwill impairment, and the other value need not be determined. Presumably, the majority of firms will test for impairment by determining value in use, given the absence of an active market for most CGUs (Shoaf and Perez Zaldivar, 2005). It should be noted that the Swedish Financial Accounting Standards Council (Redovisningsrådet) has translated and issued IASs and IFRSs in Sweden for more than a decade. As a consequence, impairment tests under IAS 36 have been in use for a number of years prior to the adoption of IFRS 3.

IFRS 1 (First-time Adoption of International Financial Reporting Standards) contains instructions on how to carry out the transition to IFRS to ensure retrospective comparability. However, the standard allows first-time adopters a number of exemptions including the option of a prospective adoption of IFRS 3. First-time adopters with capitalized goodwill have the following 
decisions to make at the time of adoption: (1) whether to make a retrospective or a prospective adoption, and if a retrospective, when to start, (2) whether to reclassify goodwill created by past acquisitions (up until 2004) to other intangible assets, (3) the economic life of reclassified goodwill, and (4) whether goodwill created by past acquisitions ought to be impaired in the IFRS restatement (in addition to those made under local GAAP).

\section{Theoretical background and research hypotheses}

\subsection{Effects of the adoption on financial statements}

Goodwill accounting has been a controversial topic for decades. In the early 1970s, the APB's Opinion No. 17 (Intangible Assets) was criticized because the shift from manufacturing to 'knowledge-based' activities would result in acquiring firms' values being too dependent on something untouchable (Jennings et al., 2001). However, acquired goodwill is a consequence of an actual business transaction, and therefore, it cannot be ignored. Empirical evidence suggests that while the level of goodwill explains differences in value across firms (Jennings et al., 1996), goodwill amortizations provide little valuable information to investors (Kirkham and Arnold, 1992; Jennings et al., 2001; Moehrle et al., 2001). An important point is, however, that in the U.S., where much of this research is conducted, goodwill amortization expenses were rarely disclosed, and hence there is no research documenting whether goodwill amortizations are irrelevant or not.

Goodwill is the price paid for future excess operating returns and it is well-documented that over time, operating returns are mean-reverting (Nissim and Penman, 2001). Arguably, we do not know the mean-reversion pattern of individual firms, but in the past, standard-setters have conservatively kept the value of capitalized goodwill low. A conservative accounting system ensures that assets are not overstated (Basu, 1997) and consequently it not only imposes explicit constraints and reduces managers' opportunities to introduce biases (Watts, 2003; LaFond and Watts, 2008), but it also reduces managers' ability to manipulate earnings (Chen et al., 2007). All accounting systems exhibit conservatism to some degree and there are known systematic variations across firms depending on institutional (e.g. Ball et al., 2000) and corporate governance 
factors (LaFond and Roychowdhury, 2008; García Lara et al., 2007; 2008). Firms with weak corporate governance mechanisms in place tend to be less conservative in their financial reporting (García Lara et al., 2008). In fact, LaFond and Watts (2008) argue that conservatism is a value-increasing corporate governance mechanism. The consequence of the rather conservative accounting approach where goodwill is systematically amortized regardless of the mean reverting pattern was primarily that the opportunities to opportunistically or mistakenly report excessive goodwill amounts were reduced.

The reasons why the IASB turned to an impairment-only approach instead of amortizations are not obvious. Clearly, the move parallels the development promulgated by the FASB, ${ }^{2}$ but the IASB has currently moved further in the direction of value-based measures than the FASB, especially with respect to non-financial assets. Hitz (2007) points out that the shift to value-based measures fits into a more general development towards the asset-liability approach, emphasizing the need to report relevant information in the balance sheet. Importantly, neither the cost-based amortization nor the value-based impairment-only approach has cash flow effects. If amortizations poorly reflect a mean-reverting pattern, perhaps impairment tests are more informative? For such an argument to be true, the increased discretion introduced must signal private useful information of the future performance of business units.

The adoption of the impairment-only approach did not introduce stricter recognition criteria, and therefore, it is unlikely that goodwill impairments under IFRS 3 are larger than the combined value of amortizations and impairments under Swedish GAAP. ${ }^{3}$ We expect most managers not to make larger impairments than what they deem absolutely necessary. The rationale for such a decision is likely to be that future cash flows are sufficient to retain the current value of capitalized goodwill; a signal of positive private information to investors. Hayn and Hughes (2006) find that goodwill write-downs are difficult to predict using historical information of the acquired entities' post-acquisition performance. Goodwill impairments lag behind the "economic impairment of goodwill" by on average three to four years and for one-third of the sample the lag 
could be as much as ten years. Overall, we predict that goodwill impairments under IFRS 3 are less than the combined value of goodwill amortizations and write-downs under Swedish GAAP.

Hypothesis 1: Goodwill impairments under IFRS are smaller than the combined value of goodwill amortizations and write-downs under Swedish GAAP.

Hypothesis 1 is an effect of discretionary decisions augmented by primarily IFRS 3, but also IFRS 1. In particular, choices relating to IFRS 1 are available at the time of adoption only, whereas choices relating to IFRS 3 (i.e., the impairment decision) are ongoing after the adoption of the standard. Both IFRS 1 and IFRS 3 provide managers with choices that are largely unverifiable for external parties (Watts, 2003). Numerous studies of accounting changes suggest that managers use discretion in response to economic incentives (Francis et al., 1996; D'Souza et al., 2000; Fields et al., 2001; Beatty and Weber, 2006; Ramanna and Watts, 2009). ${ }^{4}$ We make use of these incentives when analyzing choices particular to the initial adoption of IFRS 3.

\subsection{Determinants of how the change was implemented}

At the time of the IFRS 3 adoption, firms need to consider which adoption strategy to use and decide whether to make a prospective or a retrospective adoption. A prospective adoption means that the opening goodwill balance (in our case the opening balance of 2004, the comparative year) is kept in aggregate without any adjustments of aggregated amortization. Acquisitions during the comparative year are restated and accounted for as prescribed by IFRS 3. A retrospective adoption, on the other hand, means that the firms elect to restate all business combination applying IFRS 3 from a chosen point in time up until the adoption. In either case, the goodwill balance at the time of the adoption will be tested for impairment under IAS 36, and in either case, the adjustment is charged to the beginning retained earnings of the comparative year. At the time of the IFRS 3 adoption, managers have an opportunity to impact the size and the timing of goodwill write-downs as a part of the estimations involved in testing for impairment. They can either write-down goodwill without taking it through the income statement to inflate future profits, or they can avoid doing so and thereby postponing potential impairments to the future. 
The choice to impair goodwill is likely to vary across firms. The extant literature suggests a number of incentives determining managers' behavior in situations when accounting discretion is allowed (Myers et al., 2007; Beatty and Weber, 2006; Fields et al., 2001; Francis et al., 1996).

Hypothesis 2: Economic incentives determine the choice to make goodwill write-downs with the initial adoption of IFRS 3.

In particular, we identify four incentives influencing the behavior at the initial adoption of IFRS 3: the degree of covenant slack, equity market concerns, management's compensation scheme, and the length of management tenure. A number of studies document a tendency to avoid accounting choices that negatively affect balances included in debt covenants calculations (Beatty et al., 2002; Ramanna and Watts, 2009; Beatty and Weber, 2006). Specifically, Beatty et al., (2002) shows that borrowers are prepared to pay higher interest rates to keep voluntary (flexible) accounting changes included in covenants calculations. We expect firms with less covenant slack will have greater incentives not to impair goodwill at the initial adoption of IFRS 3 since they thereby would reduce equity, increase leverage and be closer to a violation of debt covenants.

Furthermore, previous research suggests a tendency to minimize negative effects on targeted earnings numbers when choosing among different strategies in response to new accounting standards (Jeter et al., 2008). In particular, Beatty and Weber (2006) find at the adoption of SFAS 142, firms which need to meet or beat forecasted earnings who expect to report future goodwill impairments as part of income from continuing operations are more inclined to take a larger initial write-down reported as an adjustment caused by a change in accounting standards. Moreover, further research shows that this group of firms is subsequently less inclined to impair goodwill in years following the adoption of SFAS 142 (Godfrey and Koh, 2009). We expect firms with high equity capital market concerns (i.e., a need to meet or beat earnings forecasts) will have greater incentives to impair goodwill at the initial adoption of IFRS 3 to protect future income flows from continuing operations compared to those with less equity market concerns.

In general, earnings-based managerial compensation is negatively associated with the reporting of discretionary write-downs like goodwill impairments or restructuring charges (Francis et al., 
1996). Earnings-based managerial compensation is also a determinant in the choice of incomeincreasing voluntary accounting changes over income decreasing voluntary accounting changes (Beatty and Weber, 2003). Considering that there are indications that such compensation is negatively associated with goodwill impairments at the initial adoption of SFAS 142 if it was calculated including in the income decreasing write-off, we expect firms with earnings-based managerial compensation will have greater incentives to impair goodwill at the initial adoption of IFRS 3 to boost future earnings and performance measures (Beatty and Weber, 2006).

Finally, management tenure has also been found to affect the tendency to write-down the value of assets. Francis et al. (1996) find that discretionary write-downs are more likely if there has been a recent change in key management. Other studies show evidence of the other side of the coin, namely that firms where the management has been involved in the acquisition are less likely to impair goodwill as this would be seen as an admission of failure (Hayn and Hughes, 2006; Beatty and Weber, 2006). Therefore, we expect firms with management with longer tenure to have greater incentives not to impair goodwill at the initial adoption of IFRS 3.

\subsection{Stock market reactions to the adoption of IFRS 3}

Changes in the value of equity are driven by changed expectations of future cash flows to equity or the cost of equity capital. When firms with capitalized goodwill adopt IFRS 3 this is likely to result in increased current earnings while the underlying cash flows are unaffected. We introduce two reasons as to why stock returns are associated with, presumably, disappearing goodwill amortizations. One reason is that naïve investors over-emphasize bottom-line accounting earnings. Studies in experimental psychology suggest that decision-makers do not consider all available information when making decisions (Fiske and Taylor, 1991). These findings also apply to financial accounting information and e.g. Libby et al. (2002) review studies that document inefficient equity markets and document a number of reasons as to why investors' use of accounting information is biased. The finance and accounting literature reports evidence of apparent market mispricing of accruals (Sloan, 1996; Xie, 2001; Dechow et al., 2008). In the light 
of such findings, Hirshleifer and Teoh (2003) develop a model where more salient information that requires less cognitive processing is more extensively used by investors and is to a greater extent reflected in stock prices. Investors that over-emphasize bottom-line accounting earnings will incorrectly perceive higher current earnings as evidence of a better competitive position and higher future cash flows.

A different reason as to why market values change is that investors previously viewed goodwill amortizations as an irrelevant consequence of past investments and that the size of the amortization was independent of the success of the business combination and did not provide investors with relevant information. Possibly a sustained goodwill balance under IFRS 3 is a strong indication of large future operating cash flows, and impairments a stronger indication of the opposite. In summary, we have two separate reasons as to why abolished goodwill amortizations will have an effect on stock returns.

Hypothesis 3: The effect of abolished goodwill amortizations on earnings is positively associated to stock returns in the IFRS transition period.

\section{Methodology}

We use information from OMX Nasdaq to ensure that all firms listed at the Stockholm Stock Exchange (SSE) in the years 2001 to 2007 are included in the initial sample. Table 1 shows that the number of firms listed at the SSE has decreased during the studied time period. The reduced number of firms reporting under foreign GAAP is due to the contemporaneous European switch to IFRS in year 2005. Firms that voluntarily adopted IFRS prior to 2005, firms that apply foreign GAAP, and real estate and investment companies are excluded from the analysis. In total, we have 1,691 observations (232 to 254 per year) as we analyze long-term changes in the accounting for goodwill. In the analysis of the IFRS transition we first use data from all 224 firms that provide IFRS restatements in their annual report ${ }^{5}$, except real estate and investment firms. The behavior at the initial adoption of IFRS 3 is analyzed using data from the 180 firms withh 
goodwill in 2004. We examine stock market reactions to the IFRS adoption using information from all 226 firms that were listed at the SSE in the end of November 2004 (excluding real estate and investment firms).

[Insert Table 1 about here]

Accounting and capital market data is gathered from the SixTrust database and subsequently supplemented with manually collected data from annual reports. Specifically, we collected information on the amortization, impairment and value of (1) goodwill, (2) other acquired intangible assets, and (3) internally generated intangible assets. We also used information from all firms' 2004 quarterly reports and their IFRS restatements (in the 2004 annual reports). Very few firms do not provide a detailed classification of their intangible assets in the annual report. ${ }^{6}$ All firms listed at the SSE and reporting under Swedish GAAP or IFRS specify the value of goodwill, together with goodwill amortizations and impairments in their annual reports.

Hypothesis 1 tests for differences in goodwill reductions before and after the adoption of IFRS 3 . To avoid hindsight bias we observe market values in April and pair with accounting information from the latest annual report. For most firms, this means accounting information from the year ending in December of the previous year. To test hypothesis 1 we use information on the total reductions in the value of goodwill that are expensed in the income statement. For the Swedish GAAP part of the sample we add goodwill amortizations to write-downs and scale it by total assets (GWRED). For the IFRS part of the sample we calculate GWRED as goodwill impairments scaled by total assets. We compare before and after the implementation of IFRS 3 using a dummy variable taking on the value 1 if the firm reports according to IFRS, otherwise 0 . The level of goodwill can vary over time and therefore we use goodwill, scaled by total assets, (GW) as a control variable. In addition, we control for size, (SIZE) measured as the natural logarithm of the market value of equity in April year t+1, and book-to-market (BOOKMKT), measured as the market value of equity in April year $t+1$ divided by the book value from the latest annual report announced prior to April year t+1. For all three variables (GW, SIZE and BOOKMKT) we also construct IFRS interaction variables. ${ }^{7}$ 
$G W R E D_{t}=\beta_{0}+\beta_{1} \cdot D_{-} I F R S_{t}+\beta_{2} \cdot G W_{t}+\beta_{3} \cdot I F R S * G W_{t}+\beta_{4} \cdot S I Z E_{t}+\beta_{5} \cdot I F R S * S I Z E_{t}+\beta_{6} \cdot$

$B O O K M K T_{t}+\beta_{7} \cdot \operatorname{IFRS} * B O O K M K T_{t}+\varepsilon_{t}$

Hypothesis 2 tests for management's choices related to the adoption of IFRS 3 . At the time of adoption, firms were to comply with IFRS in the first accounting period starting from January 2005. According to IFRS 1 all firms must provide investors with a discussion of the effect of the IFRS adoption and restatement of its 2004 key financial figures. Nearly all firms do so in the 2004 annual report, but a few firms choose to do it in a separate report or in the Q1 2005 report. Whenever the case, we use this information in our analysis as it neither leads nor lags the release of the annual report by more than three weeks. IFRS 1 requires that firms, at least, announce the expected effects on net earnings and shareholder's equity. In reality, almost all firms provide more detailed information and specify goodwill and intangible assets whenever appropriate. ${ }^{8}$

Previous research suggests that management's behavior at the adoption of new accounting standards could be driven by individual- and firm-specific incentives. We test for four different economic incentives that potentially affect the initial adoption of IFRS 3: covenant slack, equity market concerns, earnings-based compensation, and management tenure. Similar to Haynes and Hughes (2006) and Beatty and Weber (2006) we run a Probit regression to assess the probability of firms reducing goodwill in the initial adoption of IFRS 3.

$G W R E V A L(0.1)=\alpha_{0}+\alpha_{1} \cdot D E B T_{t}+\alpha_{2} \cdot B E T A+\alpha_{3} \cdot D_{-} \operatorname{COMP}_{t}+\alpha_{4} \cdot D_{-} E N T R E N_{t}+\alpha_{5} \cdot S_{I Z E_{t}}+\cdot$ $\alpha_{6} \cdot R T O T_{t}+\alpha_{7} \cdot G W_{t}+\alpha_{8} \cdot \operatorname{CLOSE}_{t}+\varepsilon_{t}$

The independent variable, GWREVAL, takes on the value of 1 if a firm chooses to revaluate and report impairments of the goodwill balance, and 0 otherwise. We use a measure of interest bearing debt to equity as a proxy for the degree of covenant slack (DEBT). The measure used to capture the degree of management's equity market concerns is the firm-specific beta $(B E T A)$ measured as the abnormal return calculated using the market model. ${ }^{9}$ Earnings-based compensation $\left(D \_C O M P\right)$ is a dummy variable taking on the value of 1 if management is compensated using an earnings-based bonus scheme, otherwise 0 . We measure management tenure by letting a dummy variable (D_ENTREN) take the value of 1 if the CEO in year t-5 if 
either the CEO or chairman of the board in the end of year t, otherwise 0 . In addition, we control for size, profitability, the relative level of goodwill balances and ownership concentration. We measure size $(S I Z E)$ as the natural logarithm of the market value of equity in December 2004. Profitability $(R T O T)$ is the net earnings divided by average total assets (measured under Swedish GAAP) in year t. The relative level of goodwill balances $(G W)$ is measured as the value of capitalized goodwill divided by total assets at the end of year t. Finally, we measure the degree of widespread ownership (CLOSE) as the percentage of shares held by the five largest shareholders (the data is obtained from Sundqvist, 2005). ${ }^{10}$

Hypothesis 3 concerns investors' reactions to the IFRS 3 adoption. We construct two portfolios; one consisting of goodwill-intensive firms and one consisting of firms that have no capitalized goodwill. If IFRS 3 leads to smaller goodwill accruals this increases the reported earnings of the former portfolio. The difference between the two portfolios' returns is observed in a period of time when we expect that investors will observe changes in earnings that are caused by IFRS 3. For two reasons it is unlikely that changes in investors' expectations about the future (if any) occur at specific dates: First, the investors' perceptions are likely to be influenced by market-wide factors such as articles in the business press. Second, investors' perceptions will be more affected by early providers of annual reports than late providers.

The portfolios are formed well before the adoption of IFRS 3, but not before Swedish media took notice of its consequences (Dagens Industri, Nyhetsbyrån Direkt). Most firms carried out the first analysis of the effect of the IFRS transition in the Q4 2004 report. ${ }^{11}$ We therefore analyze the seven months between $1^{\text {st }}$ of December 2004 and the $30^{\text {th }}$ of June 2005 (transition window). By then, all firms with calendar fiscal years have reported both an IFRS restatement and its first IFRS based quarterly report. ${ }^{12}$ The sample contains all 226 firms reporting under Swedish GAAP and who are listed on December $1{ }^{\text {st }} 2004 .{ }^{13}$ Portfolios are formed on the basis of goodwill scaled by total assets $(G W)$. For reliability reasons we use information from the latest annual report issued prior to December $1^{\text {st }} 2004$. A comparison is made of the dividend-adjusted abnormal returns of the decile of firms with the highest GW to the returns of firms with no goodwill (and hence are 
unaffected by the IFRS 3 adoption). ${ }^{14}$ To ensure the robustness we make controls for abnormal earnings, size and book-to-market. These controls are further described in the empirical section.

\section{Empirical findings}

\subsection{Effects of the adoption on financial statements}

Table 2 reports the level of and changes in goodwill and intangible assets over the years 2001 to 2004 under Swedish GAAP and 2005 to 2007 under IFRS. While the abolishment of goodwill amortizations led to larger goodwill impairments the additional impairments are much lower than what the amortizations reported under Swedish GAAP were. Goodwill impairments decreased from $2.1 \%$ under Swedish GAAP, to $0.4 \%$ under IFRS ${ }^{15}$ and total goodwill reductions decreased from 3.7\% under Swedish GAAP to only 0.4\% under IFRS. ${ }^{16}$

[Insert Table 2 about here]

The amount of goodwill decreased steadily in the years prior to the IFRS adoption only to increase substantially thereafter. In 2007 , the average goodwill balance has doubled compared to 2004. This increase in goodwill balances is partially driven by an increased acquisition activity between 2006 and 2007, but also by the retroactive implementation of IFRS 3 in 2004 . The total amount of intangible assets also increases in the studied time period. Like goodwill, the specific acquired intangible assets (e.g. patents, trademarks and licenses) and internally developed intangible assets increase steadily between 2004 and 2007. Under IFRS 3, acquiring firms must, if possible, identify and separately report specific acquired intangible assets. This increased the extent of such intangibles, but the increase between 2004 and 2007 is only $1.6 \%$ (including acquisitions of non-goodwill related specific intangible assets), while the increase in goodwill is $5.1 \%$. Hence most of the goodwill was never recognized separately.

[Insert Table 3 about here] 
Table 3 displays the results from the regression analysis used to test hypothesis 1 . We use both a fixed-effects estimation (to control for time-specific effects) and a Tobit estimation (as the dependent variable is censored between 0 and 1). ${ }^{17}$ Table 3 shows the effect of the adoption of IFRS 3 on goodwill reductions (GWRED). We control for the level of goodwill (GW), Size (SIZE) and book-to-market (BOOKMKT). We also interact all variables with the IFRS indicator. As predicted, the IFRS indicator is negative and significant (p-values: 0.017 and 0.000$)$ which suggests that goodwill reductions decrease after the IFRS 3 adoption. In general, firms with more goodwill in their balance sheets make larger amortizations and impairments (p-values: 0.001 and 0.000). However, we find a shift in the association between GWRED and GW following the adoption of IFRS 3. When goodwill amortizations were abolished firms with substantial amounts of goodwill no longer made large reductions. Interestingly enough, we also find that large firms have significantly smaller goodwill reductions ( $p$-values: 0.000 and 0.000$)$, but this effect partially disappears after the adoption of IFRS 3. One explanation to this could be that they amortized goodwill over a longer time prior to the adoption of IFRS 3.

\subsection{Determinants of how the change was implemented}

Panel A of Table 4 reports that among the 224 firms providing IFRS restatements 180 firms (80.4\%) report goodwill, or changes in goodwill, in their 2004 financial statements. ${ }^{18}$ Most firms with capitalized goodwill stated in their IFRS restatement that IFRS 3 constitute the most important effect on their financial reporting (93.3\%).

Under Swedish GAAP 34 firms make an impairment of goodwill in 2004. In the IFRS restatement, 21 firms make an additional impairment charge under IFRS. Out of these 21 firms, 12 did not make any impairment under Swedish GAAP and in total 43 firms make impairments under IFRS. Not a single firm makes additional IFRS impairments larger than its 2004 goodwill amortization (under Swedish GAAP). The total value of the additional impairments is MSEK 348.5 , to be compared with the estimated value of abolished amortizations of MSEK 16,024.1 in year 2004. In the transition year, 14 firms revalued acquisitions and 36 firms reclassified goodwill 
from past acquisitions (2004 and earlier) to a specific acquired intangible asset. The value of these reclassifications amount to MSEK 2,951.9 which is less than $1 \%$ of the total value of capitalized goodwill in year 2004 (untabulated results). Finally, we find that 10 firms reverse a restructuring reserve created in conjunction with past acquisitions and 11 firms reverse negative goodwill arising from past acquisitions.

[Insert Table 4 and 5 about here]

Panel B of Table 4 shows that for the 224 firms included in the sample the average net earnings increase with $17.8 \%$ from the mandatory adoption of IFRS (from MSEK 609.8 to 705.9). Most of this increase relates to goodwill-intensive firms, as the abolished goodwill amortizations, calculated also on firms with no goodwill, make up $82 \%$ of the total change in earnings. Net earnings scaled by total assets increase with $1.5 \%$ because of the abolishment of goodwill amortizations. We also note that the effect on equity is less pronounced and that the goodwill effect constitutes a minor part of the total balance sheet effect.

The test of hypothesis 2 is presented in Table 5. We use a standard Probit regression model using data from the 180 firms reporting goodwill in 2004. As reported in Panel A of Table 5, firms with tenured management are likely to rely more on debt than equity financing. We also find that large firms are on average more likely to pay earnings-based compensation and they are more profitable. This supports the sign of the coefficient in our test of goodwill impairment behavior in the year of transition. However, as discussed above, the coefficient is insignificant. Furthermore, firms with a less dispersed ownership structure are, on average, less goodwill-intensive and more profitable, In addition, these firms are also less equity market concerned, which is reflected in the negative and significant correlation between CLOSELY and BETA. Finally, the analysis also suggests that high risk firms (more equity market concerned) relies less on debt finance, are small, less profitable and goodwill-intensive. This could be interpreted as if these firms, which are predicted to be more inclined to make goodwill impairments to secure future income streams, are unable to do so since that would reduce their equity to an unacceptable level and, they therefore, do not impair goodwill at the time of the IFRS 3 adoption. 
Panel B shows that all test variables except BETA take on the predicted sign. However, only one of these variables, $D \_E N T R E N$, is significant with a coefficient of -0.619 (two-tailed p-value: 0.086). We interpret this as some evidence that management involved in the original acquisition were less inclined to impair goodwill at the initial adoption of IFRS $3 .{ }^{19}$ It has to be emphasized that most firms chose to do nothing and hence it is difficult to identify differences within our sample. The empirical results do not indicate that there were substantial active choices made to act in accordance with economic incentives.

\subsection{Stock market reactions to the adoption of IFRS 3}

We predict that firms reporting large goodwill amortizations under Swedish GAAP will report a one-time earnings increase when IFRS 3 is adopted and the impairment test substitute amortizations. If investors interpret (correctly or incorrectly) such an increase in current earnings as an indication of higher future cash flows then stock prices will increase as well. We examine abnormal stock returns in a seven month transition window surrounding the adoption of IFRS 3 . Table 6 reports our findings as we construct portfolios on the basis of goodwill, scaled by total assets, as reported in the latest annual report prior to portfolio formation..$^{20}$ Overall, the firms earn high returns in the transition window. The (undisclosed) average absolute dividend-adjusted return is $20.0 \%$ and the abnormal return is $14.0 \%$. The goodwill-intensive firms yield an abnormal return of $24.5 \%$ whereas firms without capitalized goodwill yield an abnormal return of 8.0\%. The difference, $16.5 \%$, is statistically significant ( $p$-value: 0.024$)$. The non-parametric Mann-Whitney test of medians also suggests a statistically significant difference ( $p$-value: 0.014$)$. To ensure that the results are not driven by an underlying higher earnings growth rate we estimate the abnormal earnings for each firm using last year's earnings as a benchmark. When doing this it is particularly important to exclude IFRS 3 effects from the analysis. In the transition window most firms release two quarterly reports; one under local GAAP (Q4-04) and one under IFRS (Q1-05). If a quarterly report is released in accordance with IFRS we impute one fourth of its 2004 goodwill amortization (if any). We add these adjusted quarterly net earnings 
figures together and divide them with net earnings from the same quarters one year ago. As reported in Panel A of Table 6 earnings increase, on average, by 6.6\%. This is the increase in earnings beyond the effect of IFRS 3. Goodwill-intensive firms yield higher abnormal returns even though their abnormal earnings are lower $(+3.1 \%)$ than firms without goodwill $(+6.1 \%)$. The reason becomes evident when the effect of abolishing amortizations is studied (GWeffect). For the goodwill-intensive firms a removal of amortizations boost earnings to a much larger extent than the size of the abnormal earnings. For the full sample, the total earnings effect of removed goodwill amortizations and abnormal earnings is higher for goodwill-intensive firms (0.094) than it is for firms without goodwill (0.063). This is what caused the abnormal return. We firmly conclude that the differences in abnormal returns are not caused by underlying differences in abnormal earnings. We also see that goodwill-intensive firms are larger, but that there are no differences between the two groups in terms of their book-to-market ratios.

Next, we divide firms into two equally-large groups based on of their size and book-to-market. Panel B shows that the difference between the two portfolios remains statistically significant ( $p$ values: 0.032 and 0.016 ) for small firms. As expected, small firms have less capitalized goodwill. Again, the goodwill-intensive firms have a lower earnings growth rate but higher abnormal returns. We find no difference in terms of size and book-to-market. Large firms tend to have more capitalized goodwill and in the transition period they earn higher abnormal returns than small firms, irrespective of goodwill intensity. Interestingly enough, we find no statistically significant difference within the sample of large firms. The probable reason for this is that the increase in earnings related to the abolishment of goodwill amortizations (0.040) is not large enough to counter the underlying substantial difference in abnormal earnings (0.060). Finally, Panel C displays returns after sorting on the book-to-market ratio. In both groups the difference between portfolios are similar to those reported for the total sample in Panel A (i.e., $16.8 \%$ and $18.2 \%$ as compared with $16.5 \%$ in Panel A). The parametric and non-parametric tests of the differences show only a weak statistical significance, but we attribute part of this to a smaller sample. We note that despite that the total earnings effect of removed goodwill amortizations and abnormal 
earnings is not higher for goodwill-intensive firms (-0.036) than it is for firms without goodwill (0.068) the abnormal returns are much higher.

In summary, we find empirical evidence confirming that goodwill-intensive firms outperform firms unaffected by the IFRS 3 adoption. This effect is independent of systematic risk, abnormal earnings and the book-to-market factor. We find that the high abnormal returns are not present among large firms. However, the test of hypothesis 1 shows that large firms report lower goodwill reductions (particularly prior to the IFRS 3 adoption) and hence abolished goodwill amortizations had such a limited effect on reported earnings that it did not offset the considerably lower abnormal earnings yielded by goodwill-intensive firms. However, most goodwill-intensive firms experiencing high abnormal returns are large firms and hence we are not in any way documenting a small-firm effect.

\section{Conclusions}

IFRS 3 was the most important change at the Swedish adoption of IFRS in January 2005. This is not only suggested by the numbers reported in the IFRS restatements, but also recognized by management in the IFRS restatements. Reported earnings increased as a consequence of abolished goodwill amortizations and the long term effect (up to 2007) is an increased level of capitalized goodwill. This increase is caused partly by an increased acquisition frequency and partly by the abandonment of goodwill amortizations. That abandonment, so far, has not been accompanied by increased impairments of goodwill. We note that most firms tend not to reclassify goodwill into other, specific, intangible assets. Our test of determinants of management writedown behavior in the year of the adoption show some weak indications that managers with a tenure of at least five years tend not to write-down goodwill at the time of adoption. More than $80 \%$ of the firms with capitalized goodwill chose a prospective adoption of IFRS 3 and decided to do nothing but to reverse amortizations in the transition year. 
Firms with substantial amounts of goodwill experienced a considerable increase in earnings when IFRS 3 was adopted. We find evidence that the stock market revalued goodwill-intensive firms significantly upwards in the seven month period surrounding the IFRS adoption. Firms with no capitalized goodwill yield considerably lower abnormal returns, although they earn higher abnormal earnings. The association between the effect of abolished goodwill amortizations and the level of abnormal earnings appear important. Large firms made relatively low goodwill reductions prior to the adoption of IFRS 3 (hypothesis 1), and therefore, the effect on earnings caused by abolished amortizations was less than half of the effect for small firms. We interpret this as the prime reason to why large goodwill-intensive firms did not yield higher abnormal returns. In the U.S., where goodwill prior to SFAS 142 often was written off over a very long period of time, it appears unlikely that a similar upward revaluation of goodwill-intensive firms would have occurred. However, if the same passive adoption of IFRS 3 is experienced in other European countries, where goodwill often was amortized over shorter periods of time, it is likely that the stock market revalued goodwill-intensive firms upwards in the same manner.

We initially discussed two reasons to why goodwill-intensive firms experience higher abnormal returns within the transition window. We cannot discriminate between the two explanations but it seems more likely that investors focused on "bottom-line" earnings and saw goodwill-intensive firms as more attractive investments when their current earnings increased (regardless of the underlying cash flows). A first reason for this explanation is the apparently strong association between abnormal earnings and the effect of the abolished goodwill amortizations. A second reason is that the impairment testing requirement was in effect before the IFRS 3 adoption.

The results suggest that firms are more dependent than ever on the decision of impairing an unidentified intangible asset or not. Research in the U.S. has shown that goodwill impairments often are made excessively late (Hayn and Hughes, 2006). Given that earnings management is quite common in Europe, and that goodwill balances are considerable (and will not be smaller unless managers choose to make impairments), more research is needed to explore the effects of the specific European case. In particular, more research is needed to examine how relevant 
goodwill impairments are to investors under IFRS 3, and of how economic incentives drive the decision to impair goodwill or not. 
Table 1: Sample Selection Process

\begin{tabular}{|c|c|c|c|c|c|c|c|c|}
\hline & \multicolumn{4}{|c|}{ Swedish GAAP } & & \multicolumn{3}{|c|}{ IFRS } \\
\hline & 2001 & 2002 & 2003 & 2004 & & 2005 & 2006 & 2007 \\
\hline $\begin{array}{l}\text { Listed firms (April in year } \\
t+1 \text { ) }\end{array}$ & 295 & 291 & 275 & 270 & $\begin{array}{l}\text { Listed firms (April in year } \\
\mathrm{t}+1 \text { ) }\end{array}$ & 267 & 268 & 263 \\
\hline Foreign GAAP & -8 & -7 & -7 & -7 & Foreign GAAP & -4 & -3 & -3 \\
\hline IFRS & -7 & -8 & -9 & -12 & Swedish GAAP & -12 & & - \\
\hline Investment and real estate & $\underline{-23}$ & $\underline{-22}$ & $\underline{-19}$ & $\underline{-19}$ & Investment and real estate & $\underline{-19}$ & $\underline{-23}$ & $\underline{-26}$ \\
\hline Observations in sample & 257 & 254 & 240 & 232 & Observations in sample & 232 & 242 & 234 \\
\hline
\end{tabular}

We use all firms listed at the Stockholm Stock Exchange in the years 2001 to 2007, except for firms reporting under foreign GAAP or that are real estate or investment companies. In total, the sample consists of 1691 firm-year observations. Please note that 12 firms with non-calendar fiscal years filed their reports under Swedish GAAP in 2005. 


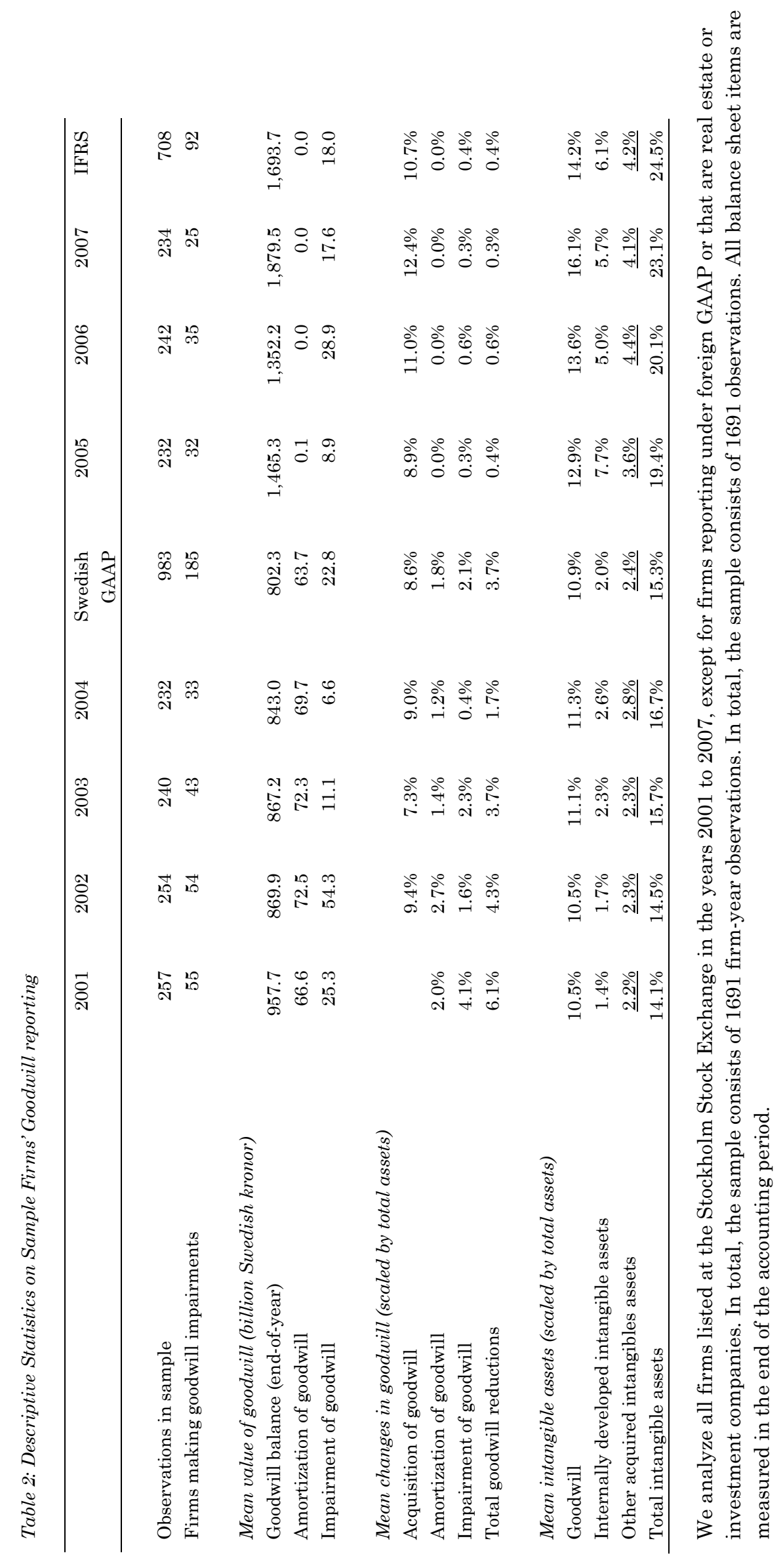




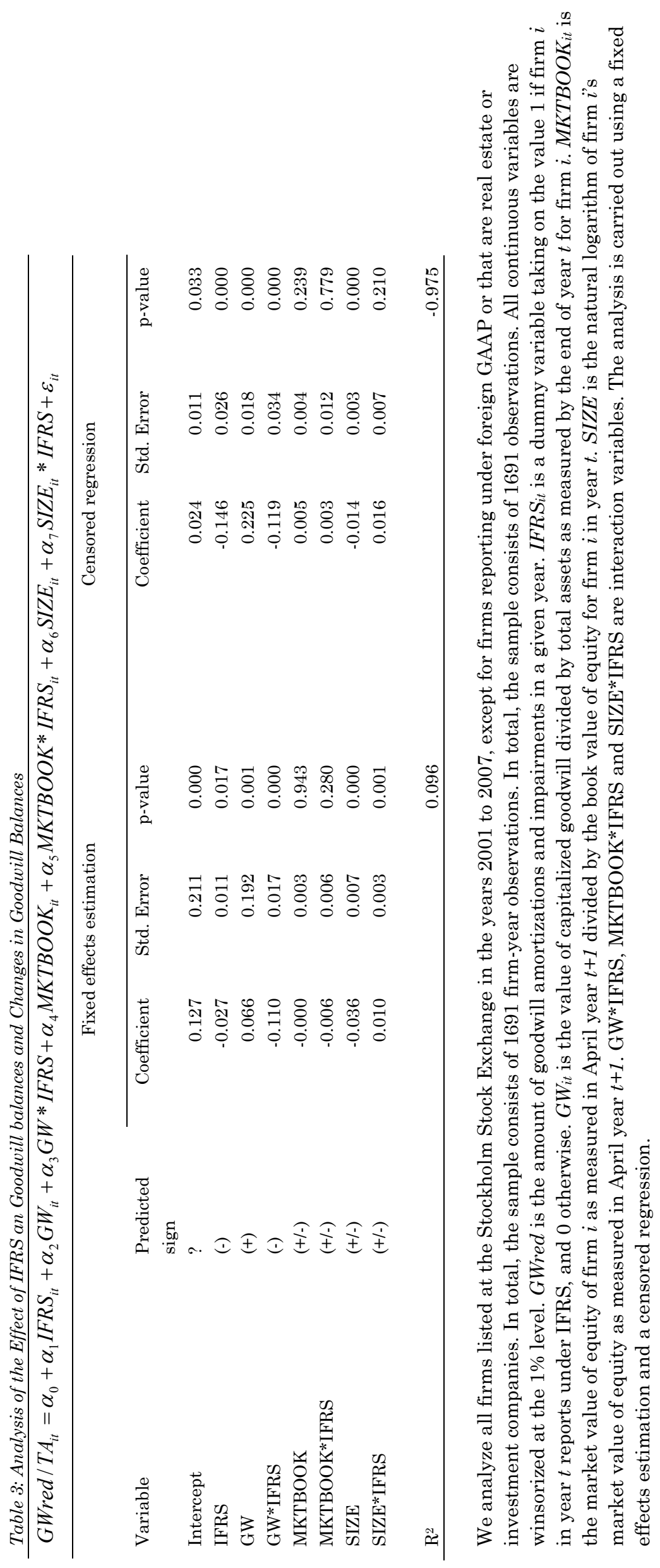


Table 4: Analysis of IFRS Restatements

Panel A: Monetary Consequences of the IFRS Adoption

N $\%$-age

MSEK

Firms with IFRS restatements

224

Number of firms reporting goodwill

under Swedish GAAP

$180 \quad 80.4 \%$

Most important change

Additional goodwill impairment

Revaluation (retrospective adoption)

Reclassification of goodwill

Removal of restructuring reserve

$168 \quad 93.3 \%$

$21 \quad 11.7 \%$

$11.7 \%$
$7.8 \%$

$20 . \%$

$5.6 \%$

368.4

Removal of negative goodwill

$6.1 \%$

\begin{tabular}{lrrrr}
\hline Panel B: Restatement Effects of IFRS 3 & $\begin{array}{r}\text { Swedish } \\
\text { GAAP }\end{array}$ & IFRS & $\begin{array}{r}\text { IFRS 3 } \\
\text { effect }\end{array}$ & $\begin{array}{r}\text { Other } \\
\text { Effects }\end{array}$ \\
\hline Mean net earnings (million Swedish kronor) & & & & \\
Mean net earnings / total assets & 609.8 & 705.9 & 87.8 & 8.3 \\
Mean equity (million Swedish kronor) & $2.5 \%$ & $4.2 \%$ & $+1.5 \%$ & $+0.3 \%$ \\
Mean equity / total assets & $4,464.8$ & $4,951.8$ & 87.8 & 399.3 \\
& $45.2 \%$ & $51.3 \%$ & $+1.5 \%$ & $+4.7 \%$
\end{tabular}

The analysis is performed on all 224 firms listed at the Stockholm Stock Exchange who (1) provide 2004 financial statements in accordance with Swedish GAAP, (2) are not a pure investment or real estate company, and (3) provide an IFRS restatement. 
Table 5: Analysis of the Propensity to Revalue Goodwill at the Time of Adoption

\begin{tabular}{|c|c|c|c|c|c|c|c|c|}
\hline \multicolumn{9}{|c|}{ Panel A: Analysis of Pairwise Correlations (p-values) } \\
\hline$D E B T$ & $\begin{array}{r}D E B T \\
1.000\end{array}$ & BETA & D_COMP & D_ENTREN & SIZE & RTOT & $G W$ & CLOSE \\
\hline BETA & $\begin{array}{r}-0.379 \\
(0.000)\end{array}$ & 1.000 & & & & & & \\
\hline D_COMP & $\begin{array}{r}-0.016 \\
(0.846)\end{array}$ & $\begin{array}{r}-0.087 \\
(0.295)\end{array}$ & 1.000 & & & & & \\
\hline D_ENTREN & $\begin{array}{r}0.219 \\
(0.008)\end{array}$ & $\begin{array}{r}-0.073 \\
(0.377)\end{array}$ & $\begin{array}{r}-0.040 \\
(0.630)\end{array}$ & 1.000 & & & & \\
\hline$S I Z E$ & $\begin{array}{r}0.067 \\
(0.422)\end{array}$ & $\begin{array}{r}-0.237 \\
(0.004)\end{array}$ & $\begin{array}{r}0.333 \\
(0.000)\end{array}$ & $\begin{array}{r}0.132 \\
(0.111)\end{array}$ & 1.000 & & & \\
\hline$R T O T$ & $\begin{array}{r}0.102 \\
(0.217)\end{array}$ & $\begin{array}{r}-0.226 \\
(0.006)\end{array}$ & $\begin{array}{r}0.245 \\
(0.003)\end{array}$ & $\begin{array}{r}0.134 \\
(0.106)\end{array}$ & $\begin{array}{r}0.368 \\
(0.000)\end{array}$ & 1.000 & & \\
\hline$G W$ & $\begin{array}{r}-0.043 \\
(0.609)\end{array}$ & $\begin{array}{r}0.344 \\
(0.000)\end{array}$ & $\begin{array}{r}-0.112 \\
(0.176)\end{array}$ & $\begin{array}{r}-0.086 \\
(0.298)\end{array}$ & $\begin{array}{r}-0.094 \\
(0.258)\end{array}$ & $\begin{array}{r}-0.278 \\
(0.000)\end{array}$ & 1.000 & \\
\hline CLOSE & $\begin{array}{r}0.112 \\
(0.178)\end{array}$ & $\begin{array}{r}-0.393 \\
(0.000)\end{array}$ & $\begin{array}{r}-0.058 \\
(0.482)\end{array}$ & $\begin{array}{r}0.138 \\
(0.096)\end{array}$ & $\begin{array}{r}0.039 \\
(0.638)\end{array}$ & $\begin{array}{r}0.236 \\
(0.004)\end{array}$ & $\begin{array}{r}-0.308 \\
(0.000)\end{array}$ & 1.000 \\
\hline
\end{tabular}

\begin{tabular}{|c|c|c|c|c|}
\hline \multicolumn{5}{|c|}{$\begin{array}{c}\text { GWREVAL }(0.1)=\alpha_{0}+\alpha_{1} \cdot \text { DEBT }_{t}+\alpha_{2} \cdot \text { BETA }+\alpha_{3} \cdot D_{-} \text {COMP }_{t}+\alpha_{4} \cdot D_{-} E N T \\
\cdot \alpha_{6} \cdot \text { RTOT }_{t}+\alpha_{7} \cdot G W_{t}+\alpha_{8} \cdot \text { CLOSE } E_{t}+\varepsilon_{t}\end{array}$} \\
\hline \multirow[b]{2}{*}{ Variable } & \multirow[b]{2}{*}{$\begin{array}{l}\text { Predicted } \\
\text { sign }\end{array}$} & \multicolumn{3}{|c|}{ Probit estimation } \\
\hline & & Coefficient & Std. Error & $\mathrm{p}$-value \\
\hline Intercept & $?$ & -0.969 & 0.961 & 0.313 \\
\hline$B E T^{1}$ & $(+)$ & -0.392 & 0.301 & 0.193 \\
\hline$D E B T$ & $(-)$ & -0.307 & 0.271 & 0.257 \\
\hline D_COMP & $(+)$ & 0.085 & 0.350 & 0.807 \\
\hline D_ENTREN & $(-)$ & -0.619 & 0.360 & 0.086 \\
\hline$S I Z E$ & $(+/-)$ & 0.020 & 0.090 & 0.825 \\
\hline RTOT & $(+)$ & -1.370 & 1.207 & 0.256 \\
\hline GWTA & $(+/-)$ & -1.441 & 1.358 & 0.289 \\
\hline CLOSE & $(+/-)$ & 0.728 & 0.765 & 0.341 \\
\hline Pseudo $\mathrm{R}^{2}$ & 0.117 & & & \\
\hline
\end{tabular}

The analysis is performed on all 180 firms that are listed on the Stockholm Stock Exchange and (1) follow Swedish GAAP in 2004, (2) are no pure real estate or investment company, and (3) have goodwill capitalized in accordance with an IFRS restatement. GWREVAL is a dummy variable taking the value 1 when a firm has made an impairment of goodwill in the IFRS restatement. DEBT is the ratio of interest bearing debt to the book value of equity, as measured according to Swedish GAAP the annual report containing the IFRS restatement. BETA is estimated using monthly observations for the 24 to 48 months (min/max) prior to December 2004. The benchmark index is the AFGX index (the most commonly used index in Sweden composed of an equally-weighted average of the largest firms). D_COMP is a dummy variable taking the value 1 when management, according to the annual report containing the IFRS restatement, has some component of its compensation tied to accounting earnings after depreciations, otherwise 0. D_ENTREN is a dummy variable taking the value 1 when the firm's CEO at year t-5 (in most cases 1999) is either the CEO or chairman of the board when the IFRS 3 is adopted. SIZE is the natural logarithm of the firm's market value of equity in April 2005. RTOT is the firm's return on total assets measured as net earnings divided by the average total assets for the year containing the IFRS restatement. $G W$ is the firm's ratio of capitalized 
goodwill to total assets, measured in the year of the IFRS restatement. CLOSE is the total voting power of the five largest shareholders, measured December $31^{\text {st }} 2004$. 
Table 6 -Difference in stock returns depending on goodwill-intensity

\begin{tabular}{|c|c|c|c|c|c|c|c|}
\hline & Abnorr & return & & & Control & & \\
\hline & Mean & Median & $G W$ & GWeff & AbnEarn & Size & $B / M$ \\
\hline Panel A - All firms & & & & & & & \\
\hline All firms & 0.140 & 0.116 & 0.119 & 0.020 & 0.066 & 3.098 & 0.532 \\
\hline Goodwill-intensive firms & 0.245 & 0.205 & 0.440 & 0.056 & 0.038 & 3.177 & 0.454 \\
\hline Firms without goodwill & 0.080 & 0.073 & 0.000 & 0.002 & 0.061 & 2.824 & 0.449 \\
\hline Difference, $p$-value & 0.024 & 0.014 & & & 0.769 & 0.095 & 0.948 \\
\hline Panel B - Size sorting & & & & & & & \\
\hline Small firms & & & & & & & \\
\hline Goodwill-intensive firms & 0.291 & 0.277 & 0.398 & 0.082 & 0.029 & 2.371 & 0.467 \\
\hline Firms without goodwill & -0.002 & -0.039 & 0.000 & 0.002 & 0.039 & 2.461 & 0.492 \\
\hline Difference, $p$-value & 0.032 & 0.016 & & & 0.961 & 0.552 & 0.828 \\
\hline Large firms & & & & & & & \\
\hline Goodwill-intensive firms & 0.215 & 0.196 & 0.466 & 0.040 & 0.043 & 3.694 & 0.445 \\
\hline Firms without goodwill & 0.239 & 0.199 & 0.000 & 0.001 & 0.103 & 3.524 & 0.366 \\
\hline Difference, $p$-value & 0.401 & 0.359 & & & 0.300 & 0.470 & 0.496 \\
\hline Panel $\mathrm{C}-\mathrm{B} / \mathrm{M}$ sorting & & & & & & & \\
\hline Low $B / M$ ratios & & & & & & & \\
\hline Goodwill-intensive firms & 0.318 & 0.238 & 0.441 & 0.046 & 0.147 & 3.330 & 0.270 \\
\hline Firms without goodwill & 0.150 & 0.126 & 0.000 & 0.003 & 0.057 & 2.967 & 0.206 \\
\hline Difference, $p$-value & 0.072 & 0.048 & & & 0.392 & 0.206 & 0.018 \\
\hline High $B / M$ ratios & & & & & & & \\
\hline Goodwill-intensive firms & 0.151 & 0.188 & 0.438 & 0.069 & -0.105 & 2.977 & 0.693 \\
\hline Firms without goodwill & -0.031 & -0.026 & 0.000 & 0.000 & 0.068 & 2.596 & 0.834 \\
\hline Difference, $p$-value & 0.061 & 0.061 & & & 0.139 & 0.227 & 0.196 \\
\hline
\end{tabular}

The analysis is performed on 226 firms listed at the Stockholm Stock Exchange at the $1^{\text {st }}$ of December 2004 and the dividend-adjusted is estimated until June $30^{\text {th }} 2005$. The abnormal return is measured as the firm's actual return less its expected return, where the latter is estimated as follows. We set the risk-free interest rate $\left(\mathrm{r}_{\mathrm{f}}\right)$, and the market risk premium $\left(\mathrm{r}_{\mathrm{m}}\right)$ to $4 \%$ and $6 \%$, respectively. We then calculate the firm's beta using monthly returns for 24 to 48 months (minimum/maximum) prior to December 2004. Firms with fewer than 24 observations (12 firms) are assigned beta 1 . Only one firm has a beta more than 3 standard deviations from the average. The expected return is calculated as: $(7 / 12) \mathrm{x}\left[\mathrm{r}_{\mathrm{f}}+8 \mathrm{x}\left(\mathrm{r}_{\mathrm{m}} \cdot \mathrm{rf}_{\mathrm{f}}\right)\right]$. Goodwillintensive firms are those firms belonging to the decile of firms with the highest ratio of capitalized goodwill to total assets according to the last annual report issued prior to December $1^{\text {st }} 2004$. Firms without capitalized goodwill are all firms without capitalized goodwill according to the last annual report issued prior to December $1^{\text {st }} 2004$. $G W$ is the ratio of capitalized goodwill to total assets. GWeff is the effect on earnings of abolishing goodwill amortizations measured as the firm's goodwill amortizations in the annual report of 2004 divided by two, and divided by shareholders equity. AbnEarn is the abnormal earnings measured as the firm's actual quarterly net earnings reported in the studied time period (1/12/2004 to 30/06/2005) less the actual net earnings of the same quarters one year earlier, and divided by shareholders equity. If a quarterly report is released in accordance with IFRS we impute one fourth of its 2004 goodwill amortization (if any). This is the increase in earnings beyond the effect of IFRS 3. Size is the natural logarithm of the firm's market value of equity at December $1^{\text {st }} 2004$. $B / M$ is the ratio of the firm's book value of equity (in the last quarterly report prior to December $1^{\text {st }} 2004$ ) divided by its market value of equity at December $1^{\text {st }} 2004$. Panel A reports an analysis based on all 226 firms. Panels B and C report separate analyses on each half of the sample (split on the basis of median market value of equity and median book-to-

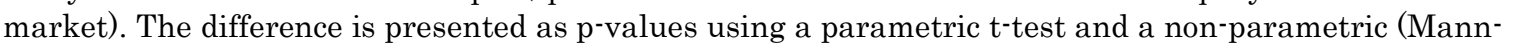
Whitney) test of medians. 


\section{References}

Ahmed, A. S. and Guler, L. (2007) Evidence on the effects of SFAS 142 on the reliability of goodwill write-offs, Working Paper: Texas A\&M University.

Alford, A. W., Jones, J. J. and Zmijewski, M. E. (1994) The extensions and violations of statutory SEC Form 10-K filing requirements, Journal of Accounting and Economics, 17, pp. 229254.

Ball, R., Kothari, S. P. and Robin A. (2000) The effect of international institutional factors on properties of accounting earnings, Journal of Accounting and Economics, 29, pp. 1-51.

Barth, M. (2006) Including estimates of the future in today's financial statements, Accounting Horizons, 20, pp. 271-285.

Basu, S. (1997) The conservatism principle and the asymmetric timeliness of earnings, Journal of Accounting and Economics, 24, pp. 3-37.

Beatty, A., Ramesh, K. and Weber J. (2002) The importance of accounting changes in debt contracts: The cost of flexibility in covenant calculations, Journal of Accounting and Economics, 33, pp. 205-227.

Beatty, A. and Weber, J. (2003) The effects of debt contracting on voluntary accounting methods changes, The Accounting Review, 78, pp. 119-142.

Beatty, A. and Weber, J. (2006) Accounting discretion in fair value estimates: An examination of SFAS 142 goodwill impairments, Journal of Accounting Research, 44, pp. 257-288.

Beaver, W. H. (1998) Financial Reporting - An Accounting Revolution. (New Jersey: PrenticeHall).

Chen, C., Kohlbeck, M. and Warfield, T. (2004) Goodwill valuation effects of the initial adoption of SFAS 142. Working Paper: University of Wisconsin-Madison.

Chen, Q., Hemmer, T. and Zhang, Y. (2007) On the relation between conservatism in accounting standards and incentives for earnings management, Journal of Accounting Research, 45, pp. 541-565.

Dagens Industri (2004) Fokus på goodwill, January 15th, 2004.

Dechow P. M. (1994) Accounting earnings and cash flows as measures of firm performance: The role of accounting accruals, Journal of Accounting and Economics, 18, pp. 3-42.

Dechow, P. M. Kothari, S. P. and Watts, R. (1998) The relation between earnings and cash flows, Journal of Accounting and Economics, 25, pp. 133-168.

Dechow, P. M., Richardson, S. A. and Sloan, R. G. (2008) The persistence and pricing of the cash component of earnings, Journal of Accounting Research, 46, pp. 537-566.

D’Souza, J. M. , Jacob, J. and Ramesh, K. (2000) The use of accounting flexibility to reduce labor renogiation costs and manage earnings, Journal of Accounting and Economics, 30, pp. 187-208.

Fields, T. D., Lys, T. and Vincent, L. (2001) Empirical research on accounting choice, Journal of Accounting and Economics. 31, pp. 255-307. 
Fiske, S. T. and Taylor, S. E. (1991) Social Cognition. (New York: McGraw-Hill).

Francis, J., Hanna, J. D. and Vincent, L. (1996) Causes and effects of discretionary asset writeoffs, Journal of Accounting Research, 34, pp. 117-134.

García Lara, J. M., García Osma, B. and Penalva, F. (2007) Board of directors' characteristics and conditional accounting conservatism: Spanish evidence, European Accounting Review, 16, pp. 727-755.

García Lara, J. M., García Osma, B. and Penalva, F. (2008) Accounting conservatism and corporate governance, Review of Accounting Studies, 14, pp. 161-201.

Godfrey, J. M. and Koh, P. (2009) Goodwill impairment as a reflection of investment opportunities, Accounting and Finance, 49, pp. 117-140.

Green, W. H. (2000) Econometric Analysis, (New Jersey: Prentice Hall).

Hayn, C. and Hughes, P. J. (2006) Leading indicators of goodwill impairment, Journal of Accounting, Auditing and Finance, 21, pp. 223-65.

Hirshleifer, D. and Teoh, S. H. (2003) Limited attention, information disclosure, and financial reporting, Journal of Accounting and Economics, 36, pp. 337-386.

Hitz, J. M. (2007) The decision-usefulness of fair value accounting - A theoretical perspective, European Accounting Review, 16, pp. 323-362.

Jeanjean, T. and Stolowy, H. (2008) Do accounting standards matter? An exploratory analysis of earnings management before and after IFRS adoption, Journal of Accounting Public Policy, 27, pp. 480-494.

Jennings, R., Robinson, J., Thompson, R. B. and Duvall, L. (1996) The relation between accounting goodwill numbers and equity values, Journal of Business, Finance and Accounting, 23, pp. 513-533.

Jennings, R., Leclere, M. and Thompson, R. B. (2001) Goodwill amortization and the usefulness of earnings, Financial Analysts Journal, 57, pp. 20-28.

Jeter, D., Chaney, P. and Daley, M. (2008) Joint accounting choices: an examination of firm's adoption strategies for SFAS No. 106 and SFAS No. 109, Review of Quantitative Financial Accounting, 30, pp. 153-185.

Johnson, L. and Petrone, K. (1998) Is goodwill an asset?, Accounting Horizons, 12, pp. 293-303.

Kirkham, L. and Arnold, J. (1992) Goodwill accounting in the UK, European Accounting Review, 1, pp. 421-425.

LaFond, R. and Roychowdhury, S. (2008) Managerial ownership and accounting conservatism, Journal of Accounting Research, 46, pp. 101-135.

LaFond, R. and Watts, R. L. (2008) The information role of conservatism, The Accounting Review, 83, pp. 447-478.

Landsman, W. R. (2007) Is fair value accounting relevant and reliable? Evidence from capital market research, Accounting and Business Research, Special issue (International Accounting Policy Forum), pp. 19-30. 
La Porta, R., Lopez-de-Silanes, F., Shleifer, A. and Vishny, R. (1998) Law and Finance, Journal of Political Economy, 106, pp. 1113-1155.

Leuz, C., Nanda, D. and Wysocki, P. (2003) Earnings Management and Investor Protection: An International Comparison, Journal of Financial Economics, 69, pp. 505-527.

Libby, R., Bloomfield, R. and Nelson, M. W. (2002) Experimental research in financial accounting, Accounting, Organizations and Society, 27, pp. 775-810.

Matolcsy, Z. and Wyatt, A. (2006) Capitalized intangibles and financial analysts, Accounting and Finance. 46, pp. 457-479.

Moehrle, S. R., Reynolds-Moehrle, J. A. and Wallace, J. S. (2001) How informative are earnings numbers that exclude goodwill amortization?, Accounting Horizons, 15, pp. 243-255.

Myers, N., Myers, A. and Skinner, D. J. (2007) Earnings momentum and earnings management, Journal of Accounting, Auditing and Finance, 22, pp. 249-284.

Nissim, D. and Penman, S. H. (2001) Ratio analysis and equity valuation: From research to practice, Review of accounting studies, 6, pp. 109-154.

Nyhetsbyrån Direkt (2004) IFRS väntas minska aktiekapital något- Morgan Stanley, 24 August 2004.

Ramanna, K. (2008) The implications of unverifiable fair-value accounting: evidence from the political economy of goodwill accounting, Journal of Accounting and Economics, 45, pp. 253-281.

Ramanna, K. and Watts, R. L. (2009) Evidence from goodwill non-impairments on the effects of using unverifiable estimates in financial reporting, Harvard Business School Working Paper, No. 09-106, March 2009.

Shoaf, V. and Perez Zaldivar, I. (2005) Goodwill impairment: Convergence not yet achieved, Review of Business, 26, pp. 31-35.

Sloan, R. G. (1996) Do stock prices fully reflect information in accruals and cash flows about future earnings?, The Accounting Review, 71, pp. 289-315.

Sundqvist, S. I. (2005) Ägarna och Makten, (Stockholm: SIS Ägarservice).

Watts, R. L. (2003) Conservatism in accounting part II: evidence and research opportunities, Accounting Horizons, 17, pp. 287-301.

Xie, H. (2001) The Mispricing of Abnormal Accruals, The Accounting Review, 76, pp. 357-373. 
${ }^{1}$ These are only recommendations and Swedish law has not decided on a maximum economic life. In 2003 RR 1:00 was altered and this paved way for using a longer economic life than 20 years whenever appropriate. In 2004 two firms (Atlas Copco and Electrolux) applied an economic life longer than 20 years.

${ }^{2}$ In an interesting study by Ramanna (2008) it is suggested that SFAS 142 , at least partly, is a response to political pressures arising from the proposal to abolish the pooling method (SFAS 141).

${ }^{3}$ However, IFRS 3 (in combination with IAS 38) specifies a more detailed testing procedure which possibly could result in different outcomes.

${ }^{4}$ There is a substantial literature on voluntary accounting method changes, both within individual countries, and between local GAAP and IFRS. As these studies are greatly influenced by factors unrelated to our study we ignore them here.

${ }^{5}$ A few firms without consolidated financial statements do not switch to IFRS as they fall outside of the EU Council Regulation 1606/2002.

${ }^{6}$ When it is not possible to distinguish between different forms of intangible assets we label them other (acquired) intangible assets.

${ }^{7}$ Another approach could be to include the control variables related to managerial discretion tested in hypothesis 2 in the model. However, we chose not to since hypothesis 1 tests the long-term effect in general while hypothesis 2 tests the behaviour at the time of the adoption.

8 When no information is provided, we assume that goodwill amortizations from 2004 are reversed and that no reclassifications of goodwill are made. This approach is verified by information provided in the 2005 annual report.

${ }^{9}$ The firm specific beta is measured as the abnormal return calculated using the market model. The risk-free interest rate is set at $4 \%$, the market risk premium is set at $6 \%$. The beta is estimated using monthly observations for the 24 to 48 months (min/max) prior to December 2004. The benchmark index is the AFGX index (the most commonly used index in Sweden composed of an equally-weighted average of the largest stocks). Firms with fewer than 24 monthly observations (12) are assigned beta 1 (i.e., the market risk).

${ }^{10}$ Another approach could be to measure the free float, the number of shares traded during a period relative to the number of outstanding shares, however, we do not believe that this would produce qualitatively different results.

${ }^{11}$ We note that a few firms opted to provide partial IFRS reconciliations already in their 2004 quarterly reports. This should lead to a partial anticipation of the effect of the accounting transition on the firm's earnings prior to the end of 2004 and create a bias that goes against our results (i.e. it can be expected that the true effect of the information on higher goodwill persistence on the valuation of goodwill-intensive firms was even higher).

12 Another approach could have been to use a longer window to measure the return, in the literature, a 12 month period starting four months after the of the fiscal year is regularly used (Alford et al., 1994). However, our judgment is that, in this case, our seven month window captures the period of time when most value relevant information about the IFRS transition enters the market.

${ }^{13}$ We trim the sample by excluding observations with returns more than three standard deviations away (three firms). The results are qualitatively unchanged from this procedure. Two firms were delisted in the transition period, but they do not affect the analysis as they both had small amounts of goodwill.

${ }_{14}$ The abnormal return is measured as the actual return less the expected return, where the latter is measured as follows. We set the risk-free interest rate $\left(\mathrm{r}_{\mathrm{f}}\right)$, and the market risk premium $\left(\mathrm{r}_{\mathrm{m}}\right)$ to $4 \%$ and $6 \%$, respectively. We then calculate each firm's beta using monthly returns for 24 to 48 months (minimum/maximum) prior to December 2004. Firms with fewer than 24 observations (12) are assigned beta 1. Only one firm has a beta more than 3 standard deviations from the average. The expected return is then measured as: $(7 / 12) \times\left[r_{f}+6 \times\left(r_{m}-r_{f}\right)\right]$.

${ }^{15} \mathrm{An}$ analysis of the composition of firms making impairment charges over time, reveals that there is some overlap but the lion's share of the write-downs made are not made by the same firms over time. During the Swedish GAAP period most firms that make impairment charges are operating in the manufacturing industry (the largest write downs are made by firms such as Skanska, Atlas Copco, Electrolux, and Ericsson) mixed with a few IT firms such as Telelogic. During the IFRS period, the prevalence of firms from the manufacturing sector is once again high (the largest write-downs are made by Skanska, Swedish Match, NCC, Trelleborg, and Volvo). Other firms that made large write-downs were Skandia (insurance) and Tele2 (telecommunication).

${ }^{16}$ It should be noted that by deflating goodwill with total assets we ignore that the value of total assets also change due to regulatory changes and related managerial choices.

${ }_{17}$ This violates the assumption that the dependent variable is continuously distributed between $-\infty$ and $+\infty$, which in turn, results in improbable predicted values, biased parameter estimates, and invalid inferences (Matolcsy and Wyatt 2006; Green 2000).

${ }_{18}$ Eight firms did not provide consolidated financial statements and hence they did not have to switch from Swedish GAAP. Twelve firms used non-calendar accounting periods and hence their IFRS restatements came later in year 2005.

19 We also run a censored regression using the relative magnitude of the goodwill impairment write-downs to total assets as an independent continuous variable. This resulted in qualitatively the same results as the Probit estimation.

${ }^{20} \mathrm{In}$ undisclosed tests we also form portfolios on the basis of information in the latest quarterly report and on the basis of goodwill amortizations. We also conduct tests where we exclude firms with negative earnings (as information about goodwill amortizations might be less relevant for loss-making firms). All of these alternative ways to form portfolios 
largely produce the same findings as those documented in the body of the paper. Our choice of portfolio formation procedure is driven by prudence and reliability concerns. 